\title{
EDITORIALS
}

\section{THEOLOGY DEPARTMENTS: BECOME INVOLVED!}

Should the ROTC be an integral part of a Catholic university? Should the college become involved in the ghetto which surrounds it? The debate on such questions will usually involve administrators, political scientists, sociologists, student government and perhaps even the philosophy department. But theology? Rarely does the department become embroiled in college disputes, even those which touch upon the value-dimensions of campus life.

More seriously, when the city opens an abortion clinic, when the local newspaper, in quest of the sensational, clearly (and perhaps deliberately) distorts Christian doctrine, when the mayor in thinly veiled racism neglects the serious needs of minorities, when the nation anguishes over amnesty or capital punishment, should theology departments sit on the sidelines? Or worse still, should the department run for cover by issuing the familiar "no comment" reply to an inquisitive reporter?

Only a few years ago, proponents for "activity-oriented" theology departments were loudly selling their wares. It was "activism" at its worst, without the true scholarship of classroom teaching and serious research. In fact, at one of the sessions of a CTS convention some years ago, a speaker declared that theology can only be taught on the picket line outside the local draft board. Theology was losing its memory and was in danger of losing its mind.

However, the answer to "activism" is not non-involvement. Perhaps the present stance of many theology/religious studies departments is part of the general apathy of the American public and the college community. Perhaps it is also part of the determination of the departments to throw off any shadow of "activism" or of proselytizing. Perhaps it is also part of the department's policy of disengaging itself completely from campus ministry so that its position within the humanities cannot be challenged. These may be so. There are, however, more serious reasons for this present-day attitude.

In some institutions, theology departments have been so weakened by the elimination of all theology requirements and the consequent firing of capable, untenured members (who, in their hopes for tenure, hesitated to speak out) that it does not have the ability to become involved even if it wanted to do so. Its meager scholarship, its poor reputation, make the department lack the respect of the academic community and its opinion is therefore not sought, or, if given, not heeded.

The apathy of theology departments, their lack of involvement in local, national and international affairs which touch upon its 
discipline also appears to be caused by a false notion of its task. Theology is, as Rahner would explain, the conscious and methodical explanation and explication of divine revelation grasped in faith. It is the self-criticism of the faith. Its critical, scholarly, methodical study of every aspect of the faith makes theology essentially oriented to testimony and witness. All theology is, therefore, in this sense, kerygmatic. We are not declaring that theology is "activism" nor is it prayer, nor is it faith, nor preaching. However, its scholarly, methodical reflection of revelation should naturally result not only in orthodoxy, but also in orthopraxis. A theology department solidly grounded in scholarship, sound teaching, critical study of God's self-disclosure in Jesus Christ, would find it difficult to remain silent when blatant errors are being proposed and lived-out within and without the university community. Involvement is the fruit of sound scholarship.

The task of the theology department is also misunderstood by the proponents of the "regressive theology" so prevalent in our age until the Second Vatican Council. Theologians considered themselves such a part of the institution that they instinctively came to its defense at all times, since "the noblest office of theology" was to show how a doctrine defined by the Church is contained in the sources of revelation (cf. Pius XII, Humani generis). This attitude spilled over into almost every field in which the American theologian was engaged so that the Church at large, the local Ordinary, the university, the government, could expect the theologians' support for all its measures or, at least, a respectful silence. The theologian was no longer considered to be a critic of the faith, the pathfinder. Rather he was to rally "round the flag," a curious type of "yes-man" within the Christian community. Perhaps some theologians have gone to an opposite extreme; nonetheless, this regressive theology with all its serious consequences still haunts many a theology department.

Another reason for this non-involvement of some of our theology/religious studies departments is the fact that the discipline has been reduced in some universities to the mere science of religion. Since the professor is not necessarily personally involved in what he is studying, theology easily becomes a mind-boggling game, much as the Sunday crossword puzzle of the New York Times. This type of non-involvement of the professor leads to his non-involvement in the practical consequences of theology. Yet, every theologian, in the fullest sense of the term, is to be a "contemplative." His life is dedicated to the critical study of the love of God in Christ Jesus, a study where knowledge and love so intertwine that they flower into contemplation. Contemplata tradere. It is the duty of the theologian to share with others, to apply the consequences of his study, to 
fearlessly let the results of his "contemplative" theology be known. Only in this way is he, in the fullest sense, the authentic theologian, the authentic critic of the faith.

Contrary to the protestations of the right wing theology/ religious studies departments have been too silent on the university, local, national and international scene. Yet, true theology cannot be gagged. Respecting the right (and obligation) of Bishops, other theologians, the laity, to assess its insights, which must be rich in scholarship and love for the Church, our departments must speak out today more loudly than ever before. Part of the agenda of faculty meetings should include practical problems of the university, Church, city and nation to which the department must address itself; if judged useful, it must take a public stand. Not to do so is to shirk one of our more difficult-and important-responsibilities.

\section{- J. PATRICK GAFFNEY, S.M.M.}

\section{DRE'S AND “THE BOTTOM OF THE BARREL": OUR RESPONSIBILITIES}

The emergence of Directors of Religious Education, or Parish Coordinators of religious education is a phenomenon to which professors of religion should be attentive. Projections indicate a need for more than 10,000 DRE's before the end of the 1970's. Factors in this projection are: (1) an extrapolation on the rate of increase of such personnel in the last five years; (2) the goal being articulated by many dioceses of placing such persons in each parish; (3) the lack of success of campaign efforts to secure government financial assistance for parochial schools; (4) the small number of DRE's presently employed in comparison with the total number of parishes in the U. S. and Canada-over 20,000.

These remarks will confine themselves to one facet of this development, namely, our responsibilities in being advocates for genuinely viable circumstances of employment for these persons. I am fully aware that there are other questions which arise, such as what are the elements in the proper professional preparation of such persons, and the emerging question of ministry and DRE's, but the scope of these remarks is necessarily limited.

At the risk of employing some older theological terms, I would maintain that we have a responsibility not only in charity but in justice to be advocates for genuinely viable circumstances of employment for these parish professionals. We have a responsibility 
in justice because many of us are involved in the academic preparation of these individuals either in graduate programs in some way oriented to the production of qualified people for these positions, or in teaching or encouraging undergraduate religion majors who may gravitate toward this line of work and service.

The situation which now exists with these positions is one of very dubious job tenure and rather frequent substandard wages. A recent study indicates two out of every five DRE's leaving their positions, with perhaps one moving to another parish and the other leaving religious education for other work. The pay scale indicates a lonely few at $\$ 12,000$ or more, but an average of about $\$ 6,000$. Understandably, religious outnumber lay professionals in this field about three to one, many of them working for $\$ 2,400-\$ 3,000$.

In this situation, we have two choices in meeting our responsibilities: (1) we can stop preparing or encouraging students for these positions, or (2) we can work to change the precariousness surrounding the DRE position. This editorial opts for the latter approach. Now to specifics.

Appropriate models for handling the problems of wages and terms of employment for DRE's are the norms for professional educators. The National Catholic Education Association has suggested that Catholic school salaries should be 80 to 90 per cent of comparable public school salaries. Generally speaking, Masters' degrees are seen as normative in terms of professional preparation for DRE's with their role being in some ways similar to supervisory jobs at the local public school. The kind of salary this approach would indicate, however, is rarely found. A great number of DRE's are religious women working for the base salaries for religious in the diocese involved. The next largest group are single women, many of whom are former religious, who for their own reasons work for extremely modest salaries. Men make up the smallest group of DRE's. Thus the typical DRE job today does not offer an economically viable lifestyle for most Catholic Christians no matter how qualified they may be. This must change. If it does not, the apparent great change in religious education, which DRE's represent, will be shown to be simply another example of the cynical maxim that "the more things change, the more they are the same."

If salaries were based, as we have suggested above, on professional qualifications and experience, more lay people, including heads of households, could thus serve in this field, and sisters who were more generously rewarded for their work could share their income with their communities. Changes like this, however, which would make reality match the rhetoric about priorities in religious education, will not come easily. At a regional 
C'TS meeting at which these ideas were touched on, an attending diocesan religious education official stated that such thinking was unrealistic, because a typical church community would come to the "bottom of the barrel" and not be able to find another $\$ 10,000$. Protestant colleagues in attendance, however, quickly pointed out that in their churches such a fundamental consideration as this did not come at the "bottom of the barrel," and many Catholics attending indicated how Catholic rhetoric stated this too.

But the "bottom of the barrel" is where this issue is now in most parts of the country. Commendably, a CTS national resolution has touched in a general way on the need for real professionalization and the kind of funding this needs, but much more needs to be done by the CTS and other professional societies. Just as important, however, will be the initiatives which departments of theology/religious studies take in lobbying on this. Indeed, here is an issue close to home which may provide an interesting first venture for those who agree with Patrick Gaffney's editorial in this issue. As large parts of this issue of Horizons indicate, we live in a time when many in theology, religious studies, and religious education have acquired a heightened awareness of political structures of city, state and nation. I would not be the first to suggest, that they have, however, been largely asleep in regard to political structures within the Church.

\section{- RODGER VAN ALLEN}

\section{CINEMA AND MORALITY}

Marshall McLuhan claims that when one environment is replaced by another, the content of the old environment becomes non-functional and aesthetic. One environment uses a chair to sit on, the next puts it in a museum. It may be non-functional, but it is appreciated as art. McLuhan's observation, it seems to me, is true except when applied to modes of communication. Just because television has replaced cinema and cinema has thus become an art form for today's culture is no reason to assume that cinema is non-functional. It would appear to be functioning quite strongly as a subtle agent of moral instruction. Films are reaching far fewer people than they did a generation ago, but they are reaching a far more clearly defined audience; and one that is predominantly young. Twenty-five years ago 75 million Americans went to the movies every week. Admissions have sagged now to 17 million a week-primarily a sophisticated youth market. 
The world of films today, this most popular of our art forms, is for the most part secular. God is at best given perfunctory mention. There is almost complete freedom in the use of language and the exposure of the body. A variety of sexual relationships is explored with an emphasis on the personal meaning of the relationship. Human sexual expression, even homosexual contact, is assumed to be normal. The harmful effects of hard drugs are clearly delineated, but the use of marijuana is taken for granted. Recently, abortion has been treated as an issue that can legitimately be raised. Popular American myths are shattered: the nobility of our early settlers, the altruism of our policemen, the purity of our wars. Mature human life is sacred; man's greatest crime against his fellow man may well be the taking of that life.

Describing the moral tone of cinema in this fashion, I would emphasize the fact that films today do not necessarily treat these themes self-consciously (although some do), but rather that this is the underlying moral climate of the best films; these are the moral assumptions of today's films. Because this moral climate is simply taken for granted, we are obviously dealing with a potent force for education to the moral, or immoral, life, depending upon our judgment.

Summer of ' 42 , an extremely popular film, is about a young boy's initiation into adult life; it assumes that sexual curiosity and experimentation are a necessary part of growth toward maturity. Another recent film on initiation into adulthood is To Find A Man; and even though it is primarily about the response of an adolescent to a man-sized problem, it assumes the legitimacy of abortion. Carnal Knowledge is about changing social attitudes with regard to sex; it assumes that obsessive preoccupation with sex is normal; in fact, obsession seems to be the only possibility. Ryan's Daughter assumes that in a strongly controlled religious environment (this one Catholic) love and marriage are uneasy bed-fellows, so to speak. The Last Picture Show delineates the possibilities for growth in a dying environment; it assumes that sexual experimentation is not only a part of the process of growing up, but also the only way, perhaps, to reach others in a disintegrating world. The assumption again would seem to be that sex is bad only when we exploit others frivolously or simply satisfy our own needs. The Boys in the Band dealt self-consciously with a variety of homosexual types, and the point seems to have been that there are no well-adjusted homosexuals. Just two years later, Sunday Bloody Sunday deals with the ways in which professional people cope with the incompleteness of life; it assumes that a mature homosexual relationship is not only possible, but also as normal as a heterosexual relationship. 
They Died With Their Boots On (1941), with Errol Flynn as a pompous but praiseworthy Custer, celebrated the courage and dignity of his last stand against the savage onslaught of the red man. Little Big Man (1971), capturing the spirit of our times, presents Custer as the megalomaniac that he probably was; it retells the story of that confrontation from the point of view of the Indians, and shows the full horror of war by showing the helplessness of its victims. Another example of the contemporary tendency to see formerly glamorous roles in an unglamorous light is The French Connection. Portraying a violent response on the part of law to big business in drugs, it makes the point that the champion of the law can be quite confused in his motivation and not above personal revenge as a driving force.

Because cinema has ceased reaching a mass audience and has become an art form for us, it is to that extent a potent force for moral instruction. It is doubtlessly a significant cultural influence on the shape of our moral lives. What films assume, i.e., the world they take for granted, can tell us a great deal about the cultural influence that is being brought to bear upon us and our children. We cannot decide on the basis of tradition alone where change must end and principle assumes control as Tevye seems to in Fiddler on the Roof. Even on principle alone he erred in disowning his daughter for marrying the Russian youth; his received tradition had already ignored the obvious teaching of Ruth and Jonah. Nor can we uncritically endorse the moral assumptions of the artists' world of cinema even though in many cases the world of the work is clearly the creation of a Christian imagination.

If Rollo May is correct in speaking of the "predictive function of art and neurosis," cinema today is of critical importance for our moral lives. "Since art is communication springing from unconscious levels," he writes in Love and Will, "it presents to us an image of man which is as yet present only in those members of the society who, by virtue of their own sensitized consciousness, live on the frontier of their society-live, as it were, with one foot in the future."

- JOHN R. MAY, S.J.

\section{DEMOCRACY IN THE CHURCH}

There is something different, I am convinced, about disaffection with the contemporary Church. It may be more a difference of degree than a difference of kind, but it is there, it is substantial, and 
it too often goes unnoticed-especially by those who are only too anxious to remind us that the Church has not been unfamiliar with disaffection in the past.

Of course the Church has been familiar with disaffection in the past. Indeed, a pessimistic view of the history of the last two thousand years would see Church life as one long sequence of heresies and schisms. Men differed persistently and deeply in their expression of doctrine, their practice of ritual, their moral decisions and their allegiance to office. Individually and communally men strove, out of a mixture of frustration and hope, to have the changes they thought necessary for the restoration of true Christianity brought about. Sometimes they succeeded, sometimes they failed; and when they failed, sometimes they saw no option open to them except to form splinter churches, rending the seamless robe of Christ.

The Arians of the fourth century fought about the correct understanding and doctrinal expression of the nature of God and of Jesus; the poverelli of the Middle Ages fought about the immorality of riches in the Church; the Eastern Catholics fought for centuries about the absolute claims of the Roman Papacy; and the great protestors of the sixteenth century fought about everything from the means of salvation itself to the nature of priesthood and the uses and abuses of ritual. There is not a single one of the four main areas of the Church's presence in the world-its ritual and code, its doctrine and institutional structure-which did not see disputes and divisions grow out of the frustrations and disaffections of its own members.

So, what's new? Just that! Our disaffected predecessors on the whole argued with the Church about the Church. Our disaffected contemporaries, by contrast, tend to profess indifference. They might argue about the Church-thereby betraying a hopeful uneasiness in their indifference-but they certainly will not argue with it. A world of difference separates the attitudes of the past, despite all their variety, from the attitudes of the present. A frustrated predecessor of ours, whether Arian or poverello, Greek Orthodox or Lutheran, would strive with prayer and power to reform his native Church and if, in that peculiar mixture of frustration at his failure and hope born of his undying convictions, he finally felt himself forced out, he would go out only to establish, or rather to reestablish the true Church. A disaffected contemporary of ours prefers to resign from active participation, to secede from structured Christian communities, to pretend that a person's religious faith is essentially a private matter.

There is no longer any real need to argue that since man is a social animal, nothing worthwhile can be maintained and developed if it is forced to forego its social dimension. And there is, therefore, 
no real need to remind anyone that the type of creative disaffection which we witnessed in the past carries as much, if not more, of a positive value-sign than a negative one. The ecumenical movement is ample proof of that. And it should be obvious to everyone that the disinterested disaffection of the present carries more a negative value-sign and leaves us to face a much more problematic future. But there is pressing need to analyze the real cause of the predominant form of present disaffection, if it is ever to be halted and reversed.

I think that the analysis is easy and the cause quite close to the surface. Listen to any of the young people with whom we are in contact, and on whom the future of the Church depends, tell why they have "left the Church," though they still profess belief in God and Jesus. When you have heard out the immediate cause of disaffection - the meaninglessness of the Mass, the Papal intransigence on contraception, the official remoteness of the chancery marriage court, the sheer unintelligibility of formulae still lingering from the Baltimore catechism-don't stop there! These are the kinds of things that have always caused disaffection, and for that very reason they cannot explain the different character of contemporary disaffection. They are now more like the symptoms rather than the real disease.

Press on, then. Try to discover-for this is the heart of the matter-why the reaction now is to secede rather than stay and cause some creative disorder. Use a recent analogy from the other great social structure. When a president used the very decline in his credibility as a reason for staying in office-thereby telling the public either that they were not judging on criteria of public morality, or that he was the judge of such criteria rather than they, or that the power of the president (his word was "strength") was more important than right-when a breakdown of public morality was discovered in administration, when the very rituals of flag and country were abused, when the constitution itself was suspected of inadequacy-did young people on the whole tend to secede? Did they ever welcome the advice to "ship out"? On the contrary. Then why is their reaction so different in the two institutions, since the same people are members of both institutions and, on their own admission, are equally interested in the values that both institutions are meant to promote? The answer, I think, is quite simply the absence of democracy in the Church, but the really critical nature of that absence needs to be appreciated.

Democracy is not an adventitious political theory. It is the latest maturity of the evolving human spirit. It coincides with the growth and expanse of knowledge, of know-how, of education. The Renaissance saw the rediscovery of the humanum, the beauty and strength, the achievements and prospects of human nature itself; the 
sixteenth and seventeenth centuries, with Galileo and Newton, knew the rise of the modern scientific spirit; the eighteenth and nineteenth centuries heard the philosophical hymn to the enlightened human reason; the nineteenth century witnessed the industrial revolution and our own century is the technological era par excellence. Knowledge and know-how is power to its possessor. As more men understand the processes of nature and the structures of social existence, they begin to gain more control over the former and to demand more control over the latter. Men who do not know, or who do not know how, can quite easily have their destinies directed by others. Advance of knowledge and technology in depth and breadth is advance of people and its social manifestation is autonomy, self-determination. Democracy is not optional in our cultural era. It is the social manifestation of the human spirit at the present state of its development and, though still suffering growing pains, it is as irreversible as the centuries which brought it about are irrecoverable. It can neither be denied to a person of our time, nor partitioned to one segment of a person's social existence-the secular, for instance, as opposed to the sacred.

There are just three things to be said about the present lack of democracy in the Church: it is all too real, there is no justification for it, and it is the root cause of the particularly destructive type of disaffection which we are experiencing in the Church today.

In a democracy people guide their own destinies through their elected representatives. In the Church, in some places, priests and people are given some part in policy-making, but their role is never more than merely consultative.

There is no justification for absence of democracy in the Church. That there is truth which people do not make true by their decision is as true of, and as applicable to monarchies and papacies as it is to democracies. It is, in other words, a truism which is irrelevant to the precise political structure of any society. That is particularly the case since no truth known to us, whether secular or sacred, makes immutable provision for the institutional structures of societies, secular or sacred.

And there is no doubt about the fact that absence of democracy in the Church is the root cause of destructive, disinterested disaffection. Modern people are increasingly unable to deal with a community so structured that it gives no opportunity for exercise of their by now natural tendency to self-determination. For this reason, all attempts to define Church primarily as the people of God, as if to say that the Church is first and foremost the people and secondarily a structured community, are at this stage cultural lies. And to us who know how much truth in its expression and embodiment is culturally 
conditioned, they are at this time straightforward lies. People of today are absolutely unable to consider themselves full, adult members of a society which still refuses to allow them to decide how they shall be ruled and by whom. And they know-not just at the top of their heads where they reflect, but at the gut-level where they experience life-that the people are not the Church and that the Church is not primarily the people of God. No eloquent preacher and no overbearing theologian, with all the exemplars and all the erudition in the world, can turn a blatant cultural falsehood into an acceptable eternal truth.

And that is why particular frustrations with particular details of creed or code, ritual or institutional office, frustrations which formerly proved occasions for creative disturbance in a Church "always in need of being purified" (Lumen Gentium), today present themselves as symptoms of a deeper disaffection. Frustrations at these particulars now remind contemporary people of their subject status in the autocracy of a hierarchical power pyramid. It reminds them that they have no control over their destinies as members of this religious community. In order to try to bring about the changes they desire in the Church they know, they have to turn themselves into impotent suppliants at the throne of power, thus reversing a development of human dignity which is centuries old, and to which Christianity itself is said to have contributed. Increasingly, then, contemporary people, and especially the more youthful of them, are unable to deal with dignity with the faults they find in their Church, and this is symptomatic of their inability to be in the Church as responsible, self-determining adults, as human beings at the present stage of development of the human spirit. That is what is meant by saying that the absence of democracy in the Church is the cause of the relatively new quality of disinterested disaffection in the Church.

What to do: Those of us who are teachers in the Church, those who write in this journal and those who read it, can continue our contribution to theory. In particular, we can continue to research the true teaching of the Founder of our sundered Christianity, and the real nature of his role in foundation. We could perhaps highlight particularly at this time his refusal and the refusal of his followers, particularly Paul, to allow any immutable institutions, laws or conventions to stand between a man and his God, while recognizing that men would always need institutions, laws and conventions to express their relationship to God. We can span the centuries between to show how the Christian faith-communities, in order to redeem the time, adapted themselves to the changing cultures, and the changing political structures, becoming all things to all men in order to show how to live out a concrete, historical faith in the changing conditions 
of real history. We could perhaps remember particularly at this point the practice of early communities in choosing their leaders, the dignity and rights of the local community as such, of which this practice was but one expression. And we can point the lesson of the "sacred time" of our origins and of the centuries between so that it reveals the freedom to adapt and the ability to redeem which we possess at present.

A word of caution is necessary at the end, however, in order to anticipate any tendency to academic chauvinism. True faith was never achieved through theology alone, though redaction criticism has recently shown how endemic was theology to the embodiment of faith from the very beginning. We should be advised by those religions of which we hear nowadays that they paid more attention to orthopraxis than to orthodoxy. I have heard it said of Judaism, and I believe it of Jesus, that it is the witness of life, borne in all forms of one's presence to the world, in living code as well as creed, in ritual practice and institutional relationships, that brings change for the better. The CTS has acted to retain the academic service of priests who have married in the Church, and this has given many cause for deep Christian gratitude. Our teaching method in the classroom is one in which we can witness by more than words to our belief that the embodiment of Christianity in democracy can enhance both faith and democracy. Beyond that, beyond academia, we are a group who can wield no small influence in the Church at large. Many are ministers of Christian sacraments, many hold pastoral positions, many are professed religious who are, willingly or not, more closely identified with the Church than others, some are in close contact with chanceries, some with more secular political structures. The ways in which we relate to our "officers of good order" in the Church, the ways in which we relate to all the people, the ways in which we try, humbly and hopefully, to vindicate true Christian freedom for all, perhaps even more than the ways we relate to our peers and our students, may carry a message of hope to those who will never read our journal and who no longer come to our classes. 


\title{
OPEN FORUM AND READER RESPONSE
}

\section{THEOLOGY AND RELIGIOUS STUDIES: A SUGGESTION}

\author{
Anne Carr
}

J. Patrick Gaffney's cogent arguments that call upon us to "Let Theology Be Theology" in the first issue of Horizons recall the departmental name shift in many Catholic colleges and universities. Does the change in orientation, when a theology department becomes religious studies, indicate a failure of nerve, or a loss of faith? Is the Catholic institution emulating its Protestant counterparts at the turn of the century, or simply adopting the state university model, structured on the church-state separation designated by the U.S. Constitution? If so, then one can only protest against such moves as destructive of the distinctive identity of the Catholic college and the genuine alternative it offers on the American educational scene. Certainly it is important to sort out the issues involved if we are to be consciously about our business both as theologians and religionists. For, on further consideration, the question becomes that of the place of theology in relation to religious studies.

In attempting to preserve the integrity of Christian theology as systematic reflection on revelation in the light of the contemporary situation, it seems clear that the task of theologizing cannot be done as of old. The instinct which has led some departments to a change of orientation is, I believe, a sound one. It is a conscious effort to abandon the parochialism and triumphalism of the past by adopting a broader approach inclusive of cross-cultural materials. Concretely, this has meant the study of the phenomenon of religion wherever it occurs: in other Christian traditions, Judaism and Islam, the variety of Eastern religious thought, native American religion, etc., as well as the vast range of cultural religious expression. Similar attempts to broaden the perspective of traditional disciplines characterize curricula in most fields today, contributing to the increased understanding of other peoples, both far and near, which is imperative in a rapidly shrinking world. Integral to this task is the study of those symbolic meanings, styles of life, and practices which cluster under the name of religion. This is the situation in which the distinctive task of theology, allowed to "be theology," must be carried forward today.

Without doubt, the consequences of such widened horizons can be fearsome. The apparent relativizing of a single symbol system when the student realizes how many different symbolic worlds there 
are-each claiming ultimate meaning-can be threatening and destructive. The many myths or religious stories which can be studied elicit the critical question of the myth or story, not only for the student but for the theologian: how can one maintain with integrity the Christian perspective within the dizzying pluralism of religious options? Or, more narrowly, which of the many interpretations of the Christian story can claim one's allegiance as true? The question is exacerbated today when Catholics designate themselves as such with little reference to traditional authorities and prescriptions from above about moral and doctrinal conditions of membership in the Church.

The prospect of adding to the relativism and pluralism which already marks our culture, by introducing further religious alternatives to college students, may seem irresponsible and self-defeating in the Catholic institution. Nevertheless, this is the world in which we and our students live and think; not only is it impossible to protect a traditional religious vision from it, but we fail in the theological vocation if we neglect reflection on faith precisely in this pluralistic context. It is my conviction that the situation is rich in potential, replete with new problems and questions. The specific challenge to theology within and enriched by the study of religion is a call for analyses and examples of how theology might fruitfully be done today. John Carmody's essay on Christology, also in the first issue of Horizons, illustrates some of the possibilities and suggests one method for further exploration.

His assumption that the study of comparative religion can illuminate the content of Christian theology recalls that of Joachim Wach who maintained that the scientific study of religion was not destructive but a source of guidance and purification to one's own theology. Chiefly, it functions to reorient theology to the fundamental norm of religious experience, the source of systematic or constructive reflection. Wach went on to indicate that theology likewise raises a question for the study of religion: can an outsider really understand the meaning and practices in a religion other than his or her own? This question led him to insist on those imponderables, requisite for understanding another religion-beyond languages and disciplined inquiry-of personal engagement and a certain breadth of experience. While it is impossible for the student of another religion to fully participate in the experience of the believer, there is suggested here a method for the study of religion similar perhaps to John Dunne's theological experiments in "crossing over" to another standpoint in order to return to one's own faith with new insight. Through such sensitive encounter on the part of Christian missionaries, the theology of mission in the Church has 
already undergone radical transformation.

The difference in orientation between theology and religious studies is clear. And even while we let Catholic schools be Catholic schools, maintaining a distinctive theological and spiritual vision at the heart of things, fidelity to the subject matter in both disciplines requires something more. There are points at which the two converge. Exploration of these points of convergence may provide insight into the unifying themes of the religious quest, as well as the particularity, depth and distinctiveness of the Christian symbols. This task, understood in terms of both methodological and substantive exploration, calls for the engagement of those who find themselves at the intersection of the paths of theology and religious studies. 


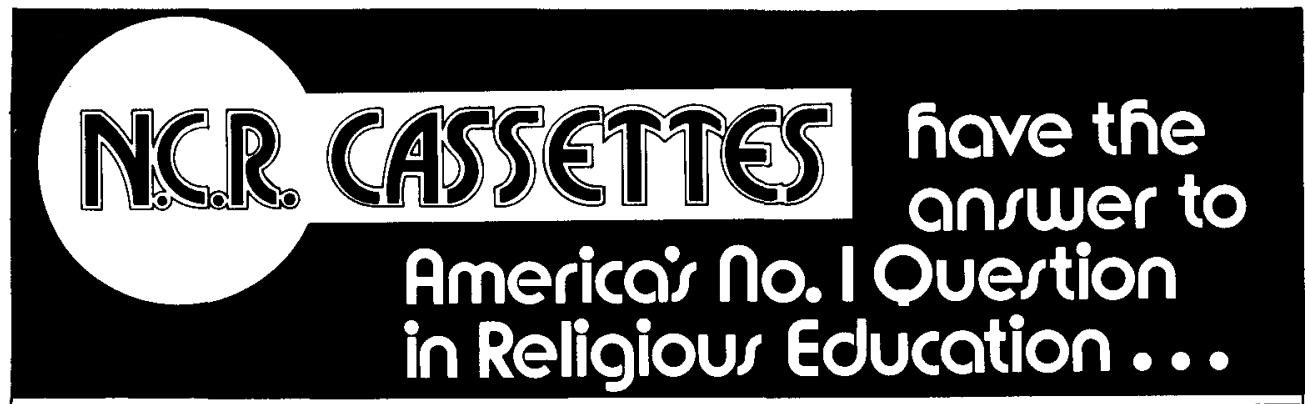

$\cdots$ HOW CAN WE TEACH RELIGION MORE EFFECTIVELY?

One of the greatest challenges facing religious education today is the preparation of catechists to meet the demands of teaching in a post-concilar church.

Whether teaching children or adults. the religious educator is faced with the continuing problem of keeping up with the latest perspectives in areas like the Bible. Wor ship. The Church Today and Yesterday. Moral Problems

\section{Ecumenical Thought. Comparative Religion and Teach-} ing Religion.

Now NCR Cassettes is making available to you a unique and authoritative teacher preparation and enrichment program at a reasonable price. This series of courses has been prepared by a nationally distinguished faculty of scholars

\section{TESTIMONIAL FROM SPONSOR}

Our Office of Religious Education has been experimenting with this teacher preparation program in twenty different areas of the diocese. The result of that experiment indicates the Religious Education teachers find this concrete program for preparedness a marvelous enhancement of their self-confidence. I would urge all parishes and schools to make whatever financial sacrifices possible in order to place the program within the reach of your own teachers.

+ Edwin B. Broderick Bishop of Albany

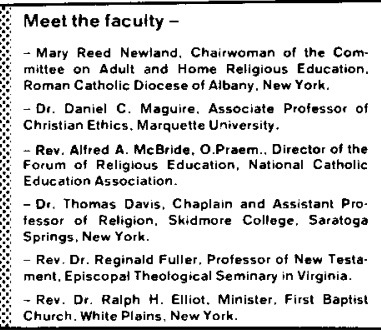

- parochial schools

- CCD programs

\section{EVERY COURSE EMPLOYS THE NEW}

AUDIO-TUTORIAL PRINCIPLE

The audio-tutorial approach to learning allows the learner to study independently, yet be systematically guided through each course.

Learning is done by the learner and not to him. The learner listens to twenty-minute lessons recorded on cassette tapes, playing and replaying them at will. Then participates in group discussions of the subject matter after every eight lessons. Because of the worthwhile interchange of ideas and concerns, essential learning takes place during the discussion periods as well.

The Study Guide for each course has explicitly stated objectives for each lesson. In addition, it gives information about the course instructor, course description, principal course objectives, course perspective, course design and material. Each course comes complete with seven study guides to supply the discussion group.

To pace learning with the audio-tutorial method, two twenty-minute lessons should be studied each week.

\section{NOTE THESE ADDED FEATURES}

- Each course is wholly contained in a vinyl covered audio-binder album, so that materials are kept together in one place and in perfect order.

- The album for each course has its own distinctive color of vinyl cover for ease in identifying the course and distinguishing it from the other courses in the series.

- Every cassette tape features a pleasing musical lead-in coupled with an introduction to the speaker and the title of the lesson to be studied.

- The labels on each cassette clearly identify the course, the lesson, and the instructor for convenience in locating or refiling in proper sequence.

- The professionally prepared Study Guides are bound in booklet form for long life and durability, and the cover color-coordinates with the album color for filing ease.

- While seven Study Guides are provided with each complete course, additional Study Guides may be ordered as required.

- NCR Cassette courses are produced under rigidly controlled laboratory conditions, and are guaranteed to please, or you may return within ten days and owe nothing.

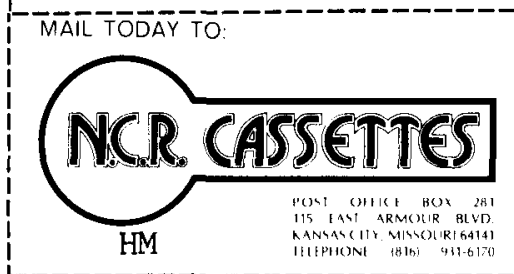

Send me FREE by first class mail complete details about your Religious Education Program. I understand I am under no obligation to buy.

Name

Organization

Street Address

City State Zip 


\title{
LIBERATION THEOLOGIES AND THE WOMEN'S MOVEMENT: POINTS OF COMPARISON AND CONTRAST
}

\author{
June O'Connor
}

As I listen to many voices speaking from within some of the liberation struggles of our century, I am struck by three recurring motifs: the presence of the theological/religious dimension as part of the socio-political analyses; the presence and importance of a new and rising consciousness; the presence of hopes and goals for the future which give purpose and direction to both reflection and action.

\section{The Theological/Religious Dimension}

It is historical fact that one of the functions of religion is that of a powerful political force legitimating the prevailing order and inhibiting change. As such a force, religion offers people a vision of life and a pattern of values which help them cope with life even when it is a life of misery and enables them to find meaning both in the present and in the world to come. It is this phenomenon which prompted Marx to criticize religion as "the opium of the people." 1

In recent decades, however, this particular function of religion has shifted dramatically. In contrast to the Marxist critique of religion as opiate which subdues the oppressed to passively accept their lot, religion is now functioning as awakener and motivating impetus evoking initiative and the spirit of rebellion. This is evident in numerous thinkers and activists. Gandhi, for example, deeply moved by the Bhagavad Gita (and the Sermon on the Mount as well), lived its emphasis on action and the importance of duty by identifying politics with religion. He saw his own political struggle as a religious act ${ }^{2}$ and tapped the religious sensibilities of his people.

${ }^{1}$ Early Writings, trans. and ed. T. B. Bottomore (New York: McGraw-Hill, 1963), p. 44.

${ }^{2}$ An Autobiography: The Story of My Experiments with Truth, trans. Mahadev Desai (Boston: Beacon, 1957), p. xii. 
Satyagraha or truth-force might be extended in paraphrase to be a kind of God-force since Gandhi felt that Truth was the only adequate name for God; his call to practice brachmacharya and to fight evil forces with goodness further exemplifies the religio-ethical concerns which found expression in his struggle for freedom.

Similarly, Aurobindo Ghose, a contemporary of Gandhi and predecessor in India's resistance movement against Britain, called his hearers to a religion of nationalism. In fact, for Aurobindo nationalism was a creed and a religion; to be a nationalist was to enter the cause of the nation in a religious spirit and to see oneself as an instrument of God. ${ }^{3}$ He saw it as God's command that India should realize the gospel of swaraj (independence) and thus achieve "the fulfilment of the Vedantic ideal in politics."

Camillo Torres, sociologist and priest revolutionary of Colombia, maintained that it was precisely Christian love which moved him to join the guerrillas in his fight against oppression in Colombia. In The Theology of Liberation Gustavo Gutierrez deals with the many questions such a commitment evokes. Basing his thought upon a totally new life experience which marks a growing number of Latin American Christians, and attempting to seriously face their theological and spiritual needs, Gutierrez confronts several key questions: "What is the meaning of faith in a life committed to the struggle against injustice and alienation? How do we relate the work of building a just society to the absolute value of the Kingdom?" What shape does one's prayer life take within the context of such a commitment? "Should the Church put its social weight behind social transformation in Latin America?",5

In A Black Theology of Liberation James Cone ${ }^{6}$ indicates that he (like Gutierrez) sees his task also to be one of doing theology within the concrete experience of oppression and in dialogue with the fundamental themes of oppression and liberation which constitute the Judaeo-Christian revelation. The Berrigan brothers are still another example of the religious motif as motivating impulse and critical voice discerning oppression both at home and abroad. ${ }^{7}$

3، The Present Situation," in Bande Mataram, vol. I of the Sri Aurobindo Birth Centenary Library (Pondicherry: Sri Aurobindo Ashram, 1972), pp. 652-653.

4 “Ideals Face to Face," in ibid., vol. 1, p. 902.

$\mathbf{5}_{\text {Trans. and ed. Sister Caridad Inda and John Eagleson (Maryknoll, New }}$ York: Orbis, 1973), pp. 135-138.

6 (New York: Lippincott, 1970).

${ }^{7}$ See, for example, Daniel Berrigan, Night Flight to Hanoi-War Diary with 
Obviously this list is illustrative, not exhaustive. ${ }^{8}$ What emerges from a reading of these religious revolutionaries is the realization that they are giving birth to a new sense of self and of community, a new consciousness that life might be otherwise.

\section{A New Consciousness}

Authors of the literature of liberation invite us, their hearers and readers, to enter into a new way of seeing. They usher us, if we let them, into a point of view which critically discerns the forces which create oppressive conditions in human life, those persons and structures which induce people to become victims of their world rather than creators and shapers of their world. These authors call us to critically discern the powerlessness that marks the daily lives of so many people. Through the writings of Paulo Freire this process has come to be known as conscientization, ${ }^{9}$ a consciousness-raising process.

A first step in such a process is to awaken those who are oppressed to see their status for what it is, a dehumanized and dehumanizing situation foisted upon them by the other who is external and alien to them. The situation stemming from these two groups is newly seen for what it is: the oppressor in contrast to the oppressed, the powerful over against the powerless, the monied versus the moneyless. Through the consciousness-raising process, people begin to entertain the idea that life might be otherwise.

Gandhi recognized the power latent in such a perspective and was deeply moved and impressed by Tolstoy's "Letter to a Hindu" in which Tolstoy does not indict the British for taking hold of India so much as he indicts the Indian people for letting Britain control them.

What does it mean that thirty thousand people, not athletes, but rather weak and ordinary people, have enslaved two hundred millions of vigorous, clever, capable, freedom-loving people? Do not

11 Poems (New York: Harper \& Row, 1971); No Bars to Manhood (New York: Bantam, 1971); The Geography of Faith (Boston: Beacon, 1971); The Trial of the Catonsuille Nine (Boston: Beacon, 1970); Philip Berrigan, A Punishment for Peace (London: Macmillan, 1969); Prison Journals of a Priest Revolutionary, comp. and ed. Vincent McGee, with an introduction by Daniel Berrigan (New York: Ballantine, 1970).

${ }^{8}$ For an extended study on the relationship between religion and revolution, see Guenter Lewy, Religion and Revolution (New York: Oxford, 1974).

${ }^{9}$ Pedagogy of the Oppressed, trans. Myra Bergman Ramos (New York: Herder, 1972). 
the figures make it clear that not the English but the Indians have enslaved themselves? ${ }^{10}$

This passage touched the depths of Gandhi's sensitivities and he had Tolstoy's words translated into Gujarati, encouraging others to translate it into additional languages to make it available to the Indian people. His hope, of course, was that this would puncture the self-consciousness of the masses and move them to action.

How the change is to be brought about raises the knotty and much discussed problem of means and could usher us into a discussion on the issues of violence and nonviolence. But that issue is beyond the scope of this article. The point here is that the consciousness-raising phenomenon is the starting point of the quest for liberation: a new perspective which evokes a new power of initiative on the part of the powerless. Awareness newly owned, consciousness newly "raised," can lead to the exploration of new possibilities in imagination and reflection. Such exploration functions as prelude to creative action designed to bring about change, to transform life from passive determinism to active participation in the creating of a new future.

Daniel and Philip Berrigan attempted to puncture the consciousness of United Statesians through the shock of unexpected gestures such as draft file destruction as well as through the words of their lectures and books - their hope, of course, to offer us all a new set of glasses, to see the war in Vietnam not as a war traditionally justifiable on the basis of self-defense, but as a war of aggression and of shocking excesses dehumanizing everyone in any way involved. Their efforts are directed to pointing out that we are a death-loving society which thrives on exploitation and on violence. Again, the theme: life might be otherwise. Therefore, the need to reflect critically, act creatively, and establish new forms of living in which justice, self-determination, and mutual reverence are established.

\section{Hopes for the Future}

Liberation literature expresses concern with strategies for overcoming the inhuman conditions under which most of humanity lives by broadening the base of power and the decision-making processes. The popular slogan "power to the people" captures something of the main thrust of these movements which seek a society in which the people determine their futures and live in a

${ }^{10}$ With an introduction by M. K. Gandhi, in Recollections and Essays, trans. and introduction by Aylmer Maude (London: Oxford, 1961), p. 427. 
world in which food and shelter, justice and dignity are known as well as discussed.

Aurobindo Ghose's hopes for India's future meant unqualified independence from Britain. This he believed would enable India to grow from her own rich resources and to become a source of liberation for all humankind. Martin Luther King dreamed of a land in which justice and freedom would overcome injustice and exploitation.

Paulo Freire words his hope as one of man growing into a situation enabling him "to become more fully human," a hope which he sees to be man's fulfillment of his "ontological and historical vocation."11 And Gustavo Gutierrez, resonant of Paul's epistles, speaks of the "creation of a new man"12 as the final goal of the many-leveled liberation process.

Having cursorily reviewed selected voices from the literature of liberation we note three points shared in common: a recognition of the revolutionary power present in theological/religious worldviews and institutions; attention to the consciousness-raising process; articulation of hopes and goals for the future in the attempt to create a new and better world. Now the question is, in what ways does the women's movement speak to and about these themes?

\section{The Women's Movement}

The history of antifeminism in the Jewish-Christian tradition has been given some attention in recent years in intellectual (and attitudinal) historical studies. These studies investigate the writings of Paul, Augustine, Tertullian, Aquinas, Luther, and Barth to mention just a few. ${ }^{13}$ Other studies focusing attention on institutional forms of antifeminism and offering recommendations for the future are available as well. ${ }^{14}$

$11_{\text {Pedagogy, pp. } 42,52 .}$

12 Theology, p. 146.

${ }^{13}$ Rosemary Radford Reuther, "Is Christianity Misogynist? The Failure of Women's Liberation in the Church," in Liberation Theology (New York: Paulist, 1972), pp. 95-114; also R. R. Reuther, ed., Religion and Sexism: Images of Woman in the Jewish and Christian Traditions (New York: Simon \& Schuster, 1974); George Tavard, Woman in Christian Tradition (Notre Dame: University of Notre Dame, 1973); Haye van der Meer, Women Priests in the Catholic Church: A Theological-Historical Investigation, trans. Arlene and Leonard Swidler (Philadelphia, Pennsylvania: Temple University Press, 1973); Georgia Harkness, Women in Church and Society: A Historical and Theological Inquiry (New York: Abingdon, 1972).

${ }^{14}$ Mary Daly, The Church and the Second Sex (New York: Harper \& Row, 
The approach which seems to deal most profoundly with the issue of antifeminism, however, is neither historical exposition nor institutionally-directed criticisms and recommendations. The sharpest manner of cutting through antifeminist understandings, attitudes, and behaviors, I believe, lies in a philosophical-theological and ethical methodology through which the antifeminist mentality is examined and assessed.

Mary Daly's Beyond God the Father ${ }^{15}$ demands serious reading because her work, brilliant and profoundly provocative, does precisely that. Her book is, in my estimation, the finest thing to date on the theological implications and import of the women's movement. I do not fully feel the anger she feels nor do I completely agree with all of her analyses and recommendations. But in a sharply critical and exceptionally creative way, she reminds us that religion is among our most profound experiences and needs to be confronted with candor in an effort to free ourselves from the causes of oppression. Since so many of these social causes are rooted in the Judaeo-Christian mind-set, its religious symbols, myths, and concepts are ripe for her analysis.

Though subtitled "Toward a Philosophy of Women's Liberation," Dr. Daly admits that the book can also properly be labeled theology if the word "can be torn free from its function of legitimating patriarchy." She is not interested (as are James Cone and Gustavo Gutierrez) in interpreting contemporary experience by locating support and legitimation in traditional doctrines. Her task, rather, is to question the fundamental assumptions undergirding those very doctrines, to challenge the "hidden agenda" which patriarchal religion contains. At the heart of her thought is the conviction that the women's revolution is a spiritual revolution intimately connected with the creative urge toward transcendence.

Daly's challenge to patriarchal religion begins with a sharp critique of the imagery of God as Father, the great patriarch in heaven who is seen to reward and punish according to his will, and includes a move to dethrone three false deities of traditional religion. The first god to be dethroned is the god of explanation whose will or plan for human life is often simply a facade for the plans of men and an easy cover for inadequacy, ignorance, and evil. Secondly, she continues, there is the god of otherworldliness understood primarily

1968), particularly Chapter Seven; Sarah Bentley Doely, ed., Women's Liberation and the Church (New York: Association Press, 1972); Clara Maria Henning, "Women in the Priesthood," Commonweal 99 (January 11, 1974), pp. 360-363; Emily Hewitt and Suzanne Hiatt, Women Priests-Yes or No? (New York: Seabury, 1973).

${ }^{15}$ (Boston: Beacon, 1973). 
as judge who rewards and punishes after death. This notion of God tends to fix the attention of society's powerless caste (women) on the future since there is so little to live and hope for in the present. Daly's call for an alternative to this is not the secularization theology of the sixties but a new and fresh and deeper discovery of the otherworldly. The third idol-god to be dethroned, she claims, is God who is judge of sin, the god who is seen and used against women to determine what are and are not acceptable attitudes, behaviors, and roles regarding birth control, their (subordinate) relationships to their husbands, passive participation in religious rituals and the like.

In so dethroning God, Daly suggests that the becoming of women involves a "radical encounter with nothingness" which has the potential for evoking an active and creative ontological hope grounded in a new surge of courage to be. It is communal and revolutionary, bearing a dynamism within the self that reaches out toward a nameless God. Yet in dethroning these gods as idols destructive to human life, Daly does not dethrone God as such, but reaches out to a more genuine way of naming the nameless One.

A second doctrine severely challenged is that of the fall, a myth which is largely responsible for rooting the mystery of evil in the feminine and thereby provoking destructive patterns in our culture. The key effects of this misnaming of the roots of evil are that it produces self-hatred in both men and women: a self-hatred in men which is directed outward toward women, and a self-hatred in women directed inward upon themselves. Because of this myth the source of evil is thrown out of focus and its deepest meanings are never really faced. The way to overcome this myth of feminine evil requires a corporate refusal by women to support or reinforce the structures of patriarchy. The strength for such corporate refusal comes from the bonds of sisterhood, the bonding of women who are oppressed by definition and who together say no to the prevailing religio-social order. Paradoxically, this bonding makes a new fall possible: a fall into freedom and into a new discovery of the sacred.

While many contemporary commentators are distressed at the fact that Christian symbols and myths are dying in our day, Daly finds the phenomenon to be a good thing, for those very myths and symbols have perpetuated oppression, thereby representing a false sense of the sacred.

Christology is a third area of doctrine subjected to Daly's critical mind. Her assessment is that Christianity is guilty of idolatry in not accepting the fact that Jesus was a limited human being. One of the implications of the women's revolution is that "exclusively masculine symbols for the ideal of 'incarnation' or for the ideal of the human search for fulfillment will not do." It seems timely, in fact, to do 
away with all images and models for God and live in a world without models. Instead of perceiving God as a Noun-embodied in one or another image-we might do better, she maintains, perceiving him as the Verb, the dynamic source and mode of being in which we all participate. The ethical implications of this language speak to the current need for overcoming the oppression which is so deep in our consciousness and patterns of behaviour.

As a uniquely masculine image and language for divinity loses credibility, so also the ideal of a single divine incarnation in a human being of the male sex may give way in the religious consciousness to an increased awareness of the power of Being in all persons. ... The point is not to deny that a revelatory event took place in the encounter with the person Jesus. Rather, it is to affirm that the creative presence of the Verb can be revealed at every historical moment, in every person and culture.

Thus, models from the past are inadequate and dysfunctional, and we are better off without them now, Daly believes, for we will not really change our consciousness until we distance ourselves from patriarchal theology and create a new one. However she does entertain the possibility that we may sense a new moment in which we need to remythologize religion, finding a need to use imagery that is non-hierarchical.

The point of Daly's criticism of the symbols, myths, and dogmas of Christian patriarchal religion is to bring to consciousness the destructive ethical implications these bear with them, legitimating attitudes and thereby creating structures of sexual caste and the oppression of half the human race.

It can be supported historically that Christian morality has tended to undervalue responsibility in both women and men, encouraging a passive ethic which supports rather than challenges forms of exploitation. The new feminist consciousness renounces such an ethical posture and affirms a way of living that has existential courage at its base, enabling women to repudiate the passive ethic both personally and politically. The new ethic renounces the mentality of "rape" and its kin the mentalities of "war" and of "genocide"; This is to say it renounces sexism in all its forms, individually-personally and socio-politically.

The feminish movement, in Daly's understanding of it and hopes for it, refuses to accept the reifying, thingfying attitudes which sexism presupposes and contains, and does so on every level-physically, psychologically, intellectually, socially. Her denunciations of the mentality of rape, which lead her to decry also the rape of other nations and cultures, ushers her into a discussion 
regarding the rape of nature as well. "This Great Refusal of rapism clearly means refusal to rape earth, air, fire, water, that is, refusal to objectify and abuse their power."

Daly's call to us to move from a "culture of rapism" to a "culture of reciprocity" touches upon a central theme in Vine Deloria's recent book, God is Red. ${ }^{16} \mathrm{He}$, too, deals with the ethical implications of the Judaeo-Christian religious myths. In a comparative ethical analysis of Christianity and Indian tribal religions, Deloria roots the major difference in contrasting attitudes toward land. While the myths of the tribal religions illustrate the interrelationship of all things, the Judaeo-Christian creation myths depict man as having dominion over the earth, opening the way for dealing with the earth as object. In different ways and from different contexts, Deloria and Daly both call us to a new reverence for the other which is land.

\section{Further Comparisons and Contrasts}

By now it is evident that although Daly speaks to and about the women's movement within a context of theological religious symbols, myths, and concepts, it is important to note what she does not do. She does not accept the religious tradition of the society and then appeal to the religious sensibilities of her readers as a means of motivating them to rebel as did Gandhi and Ghose. Nor does she attempt to recast theology within the new perspective of women's liberation, analogous to what we find in Gutierrez and Cone. Rather, her approach is to place under severe scrutiny those symbols, myths, and concepts which comprise patriarchal theology and which pervade our conscious and unconscious alike, determining so much of our behavior. Her intent is to surface the destructive powers present right within those meanings. Judging the truth and value of these long cherished understandings on the basis of what historically they have done to us, both women and men, the theological/religious dimension becomes a target of indictment and sharp critique as she uncovers their inherently oppressive implications. Her conclusions are unambiguous: the tradition bears responsibility for dehumanizing women, locating the origin of evil within the feminine experience, and so promoting hatred of women by men and self-hatred in women themselves. These patriarchal religious concepts have created barriers by establishing positions of superiority and of subordination and so of oppression; because the religio-social realm dehumanizes women it becomes easier to dehumanize non-women as well: the poor, the

${ }^{16}$ (New York: Grosset and Dunlap, 1973). 
powerless, those different racially, nationally, and culturally as well as sexually.

Unlike Gutierrez and Freire, Daly does not hope for the emergence of a new man. To do so would be to betray the point of her book. However she does clearly anticipate the becoming of liberated women and men. She hopes for the becoming of androgynous human persons marked by a psychic wholeness, by an overcoming of false dichotomies, destructive splits within the self as well as without. Daly sees the hope for the future to be entry into a new appreciating and a new living of being. In her words, "the women's revolution implies the liberation of all human beings." It is more than a particular group's struggle: "What is at stake is a real leap in human evolution, initiated by women."

Daly shares in common with Gandhi, Freire, and the Berrigans a desire to raise our consciousness, inviting us to see what she sees and to discern more critically than we normally tend to do, those circumstances, values, and ideas which give shape to and express our lives. With Freire she calls us to be creative as well as critical, to act as well as to think, to summon up the courage necessary to engage in a new independent existence, refusing to retreat from and be co-opted by sexist institutions whether religious or social.

In contrast to Gandhi's critique of his own people, Daly is reluctant to place any blame on women for the oppression which subjugates them. "It is all too easy and basically misleading to say that it is women's fault that society is sexist. This is as fallacious as suggesting that it is the fault of blacks that society is racist, or the fault of the poor that poverty exists."

Yet in the midst of the anger which permeates the book, Daly conveys a deep sense of hope. In this she shares with many voices of the liberation literature a basic posture of believing in human possibilities, believing that change can happen and that good and creative things might indeed emerge. Unlike the authors cited above, Daly focuses on the role of women in the creation of this new thing and sees that their role is crucial in initiating the change that will liberate not only women but men as well. Their role is that of "final cause," causing all other causes to cause.

The final cause is the beginning, not the end, of becoming. It is the first cause, giving the motivation to act. The feminist movement is potentially the source of real movement in the other revolutionary movements (such as Black Liberation and the Peace Movement), for it is the catalyst that enables women and men to break out of the prison of self-destructive dichotomies perpetuated by the institutional fathers. Radical feminism can accomplish this 
breakthrough precisely because it gives rise to an intuition of androgynous existence... Without the power of this vision to attract women and men so that we can will to transcend the whole array of false dualisms, there will be no real change. The liberation 'movements' that leave sexism unchallenged can, of themselves, only spin delusions of progress, bringing about endless, arbitrary variation within the same senescent system.

Within this context, Daly claims that "of all the revolutionary causes it [radical feminism] alone opens up human consciousness adequately to the desire for non-hierarchical, nonoppressive society, revealing sexism as the basic model and source of oppression." With this statement, Daly articulates her position regarding the nature of the relationship between the women's movement and other struggles for liberation and justice. Not only is the women's movement not to be dismissed or trivialized in the face of other struggles across the world: on the contrary, it is radical feminism alone which reveals the root of oppression in its analysis of sexism.

Special Focus: Beyond God the Father by Mary Daly

(Boston: Beacon Press, 1973)

Participants: June O'Connor

University of California at Riverside

Wilma Gundersdorf von Jess

Saint Anselm's College, Manchester, N. H.

Elisabeth Schüssler Fiorenza

University of Notre Dame

John E. Burkhart

McCormick Theological Seminary, Chicago

Mary Daly

Boston College 


\section{TWO CRITICAL QUESTIONS}

\section{June O'Connor}

My task in this brief space is to raise a critical question. I have two. The first is addressed to those who have read (and to those who-I hope-will read) Beyond God the Father. This book is perhaps the most serious contemporary challenge to the validity and viability of the Judaeo-Christian revelation. Pruned of all its sexist references and presuppositions, Daly feels, at most there would be enough of the scriptures left to comprise a pamphlet. One response to her thought is, of course, to dismiss her as an unbeliever. However, I would prefer a response of attentive listening and further questioning. Do her convictions and conclusions necessarily compromise revelation and the centrality of Christ? Or is she possibly more in the tradition than even she perhaps realizes? (By their fruits will you know them.) Another way of approaching this is to compare Daly's method and conclusions with Kierkegaard's essay "The Teleological Suspension of the Ethical." When facing the question regarding the relationship between revelation and ethics ("the religious" and "the ethical"), Kierkegaard opts for the suspension of the ethical in deference to the religious. Mary Daly faces the same question, yet opts for a reverse interpretation: a suspension of revelation in the name of the ethical. In other words, the validity and viability of scripture are judged in terms of what its symbols, myths, and concepts have done to us. And she finds that they have had an oppressive, destructive impact. If, in fact, the stories, myths, and images of the Judaeo-Christian revelation stimulate oppressive effects in various forms, then is there not perhaps something indeed deeply questionable about those stories and symbols themselves, even for the devout believer?

The second question is addressed to Mary Daly. You say that though many liberation movements focus their attention and energies on some specific evil within patriarchy (such as racism, war, poverty), they do not challenge patriarchy itself, and fail to recognize sexism as the key paradigm and source of all those forms of oppression. I find your interpretation arresting and persuasive. Yet as I live with your thought I find the persuasion to be unstable and short-lived. I wonder: is your claim that sexism is the source of oppression employed to counter the tendency to trivialize the place of the feminist movement? That is, is it something of an overstatement intended as a corrective? Or is your intent seriously to affirm a causal connection between the two? It is clear to me that 
both sexism and racism, for example, imply reifying, thingifying, objectifying the other, using, controlling, manipulating the other, refusing (and perhaps in time becoming unable) to revere and honor the other as other. In other words the exploitative mentality takes expression in both rapism and racism-and in many other forms as well. I am persuaded that sexism is no less important an expression of evil than are racism or colonialism or the many other forms of exploitation which support and escalate one another. Yet I question the truth and the value of the claim that sexism is the basic source of oppression if used in a causal sense.

\section{SUFFERING, "THE SCAPEGOAT SYNDROME," AND PROPHETIC ACTIVISM}

\section{Wilma Gundersdorf von Jess}

Mary Daly has written a first-rate book, one that calls for the attention of men perhaps even more than of women. Because I, too, have reached many of the same conclusions and agree with much of her analysis, I find it particularly difficult apparently to set myself in opposition to her work. However, I do wish to raise a question relative to Professor Daly's approach to the problem of woman as scapegoat, and to the implications of that for each woman's personal growth into the freedom of authentic human BE-ing.

I wonder whether it is realistic for anyone, male or female, to refuse so completely to accept any insertion into a theology of self-sacrificial love as does Dr. Daly, for it is part of the human condition for all of us sometimes to suffer injustice at the hands of others. Life is everywhere permeated by this mystery of evil. Like the author, I know how poisonous a diet continuously too rich in this fare can be: poisonous to one's self-esteem, to one's creativity and productivity, and perhaps finally even to love and life itself-two values which surely must stand at the center of each person's integrity and participation in being.

The dilemma is clear enough: the role of suffering servant breeds a mentality which would appear in the end to negate one's existential courage and even one's very existence, and therefore to destroy any positive process leading towards self-fulfillment. Moreover, when expanded from a personal to a societal level, the acceptance of this passivity by large numbers of women will continue to keep this half of the human race in a condition of servitude. Surely that must not 
be allowed to happen. Nevertheless, a closer look at the function of the suffering servant makes it clear that this prophetic role is not exclusively a passive one, for it is intimately conjoined with the activity of the prophet summoning the people of God to conversion. The suffering is therefore also actively salvific.

Furthermore, on another level of discussion, would it not be possible to distinguish what women should and must do in order to correct social injustices rooted in sexism from those injustices which each of us individually experiences? I am suggesting that the stance taken relative to the neighbor-our sister-who suffers within the framework of the patriarchal system might be different than the stance we would assume when personally pressed by similar circumstances. Would it not be possible sometimes to walk the extra mile with the enemy while at other times to block his path, exerting every effort to contain the evil he would do? The choice would of course depend on whether we ourselves or another were the victim of the unjust aggression or of the denial of rights.

I concede that it is possible to counter this suggestion by insisting that just such a fragmented and divided consciousness has been responsible for what Daly sees as woman's own self-victimization by sexual stereotype, and that therefore it is entirely inconsistent with a program of liberation; that in fact it could and does cause serious dysfunction (psychosis?) for many women. While it is true that there is a real danger here, I believe that danger can be reduced, and perhaps even be eliminated, precisely in those women who have moved gradually through the process of conscientization and are now actively engaged in affirming their identity, in creating themselves.

For these prophets (prophetesses?) at least, perhaps it is possible to do the work of righting the wrong, of speaking for our sisters and for God's own righteousness, of claiming and reclaiming woman's place under the sun, of speaking as the conscience of the world community of androgynous beings, of calling all people to transcendence (of sex, color, class, etc.); and to do this prophetic work while at the same time embracing actively that which has always been the mark of the prophet, personal alienation. It is precisely this that I find missing in Dr. Daly's presentation.

Yet I grow ever more convinced that it is this duality of being that I have described that will be in the end most productive, most creative, and paradoxically most integrating, most apt to achieve ultimate enrichment and final transcendence into freedom. Along the way, it may even bring with it a measure of peace, of bliss, of joy, as one reaches towards the Absolute in whose Being we all do share.

Dr. Daly will surely have noticed that in moving this discussion 
out of the more narrow framework of seeing Jesus as self-sacrificial model par excellence, I have attempted to underline the broader aspects of the question, and therefore at least implicitly to question the conclusions she draws in the area of Christology, conclusions with which I do not agree. Consequently I have left myself open to the accusation of having unwittingly fallen into "the fallacy of universalizing." That, however, is precisely what I am not doing, at least in the way that Daly has defined the term. Rather, I am suggesting that the conception of Divinity and of imago Dei which I am here using is not necessarily objectified only in Jesus, even though as a Christian, I do believe his position is unique.

I will be grateful for Mary Daly's response to the problematic I have raised concerning "the scapegoat syndrome," trusting that despite our difference of opinion on this and other points, she will recognize that we are one in commitment to the goal of franchising the disenfranchised, and of working with, and especially for our sisters in a way which will someday eventuate in the credible preaching of the ministry of justice in the Church.

\section{WHY NOT A CATEGORY OF FRIEND/FRIENDSHIP?}

\section{Elisabeth Schüssler Fiorenza}

My reaction to Mary Daly's book Beyond God the Father is mixed. I am happy that she wrote this excellent book-in my opinion, a most perceptive and very theological work on feminism and Christian religion. Theory and praxis, theology and spirituality are successfully united here. Reading the book gives me courage to continue the struggle and to sharpen my own theological thinking. Yet these positive reactions cannot quite overcome my basic critical questions. I therefore welcome the opportunity to share and to discuss them.

First: Mary Daly does not want to call her book a theology because she does not intend "to apply 'doctrine' to women's liberation," but to "explore the potential of the women's movement towards androgyny." Yet, instead of developing a theology derived from the androgynous experiences of women and men, she analyzes and criticizes doctrine and tradition from the perspectives and insights of the women's movement. This is justified and needs to be done. It is critical or political theology at its best, but it is not what she sets out to do. Like all polemical works the book is dependent 
upon the concepts against which it is arguing and thus derivative. A systematic theological inquiry based upon the religious experiences of contemporary women does not necessarily have to declare the identity of Christian women as false consciousness, as Daly's negative attitude to the Christian tradition does. True, this tradition must be critically exorcised and rejected, wherever necessary. But this tradition also espouses androgynous traits which are worthwhile to explore. Human persons cannot start at zero but have to live in their culture and with their tradition. The leap into total "nothingness" is a prerogative of heroines. The danger of ideology is unavoidable. In my opinion it is necessary for the sake of Christian women that the "power of naming" is extended to the Christian tradition in an affirmative way.

Second: Mary Daly does not spell out clearly enough how the androgynous goal or ideal and feminist experiences and categories are related to each other. There is a danger that her ontological approach might neglect the personal aspect of God, that her stress on the maleness of Jesus might overlook him as a person, and that her emphasis on female experience might not adequately stress the personhood of woman. To replace the father-god with the mother-goddess, to reject brotherhood in favor of sisterhood is important, but not enough. Eschatological salvation is still named with sex-typed categories. The symbol of the virgin/mother might signify the independence of women from men but it still defines women by their sex and not as androgynous persons. Daly senses the danger of feminist "totalitarianism," when she asserts that the Second Coming is not an absolutizing of women but the overcoming of dichotomous sex-stereotyping. Yet, she herself seems to be not quite able to do without scapegoating, castrating and without the "other." I agree with her that the arrival of female presence is the necessary catalyst for the qualitative leap toward psychic androgyny. However, I would like to see her recast eschatology not only in female but also in androgynous symbols pronouncing full human integrity. "Sisterhood of men" is an excellent critical formulation but it still communicates sex divisions and dependence upon a parental figure. I wonder why the author never uses the category of friend/friendship which is not sex-stereotyped and symbolizes a community of equals. Indeed the "power of naming" is given to us and I hope this dialogue helps to focus this power. 


\title{
MARY DALY: THEOLOGICAL ORPHAN?
}

\author{
John E. Burkhart
}

Pondering Mary Daly's Beyond God the Father has been a strenuous and consciousness-raising experience. Many times while reading the book, I have put it down momentarily, wondering whether I was really absorbing the full implications of its passionate message, yes, and puzzled whether the message I was receiving was the one intended. Sometimes I felt perplexed, at other times besieged, but was always intrigued by the dazzling audacity of the arguments. Thus, while I do not claim to comprehend, and doubt whether even an androgynous eschaton would proffer me a share in the wisdom of her "ovarian insights," I must acknowledge that the book is provocative. Indeed, if "passion and risk" are marks of authentic theological statement, Mary Daly qualifies as a quite remarkable theologian. In any event, she is surely one of the most radical among the theologians of hope. She is, in a word, an unabashed futurist.

As I understand her, the heart of her vision is a profound sense that we all live on the verge of a leap into a world so liberated that it resembles nothing we have ever known before. In other words, at a fundamental level of ideological commitment, she concurs with Margaret Mead's insight into "preformative" cultures, with the unquestioning instinct that the future will create human lives so novel that the past can no longer offer any useful guidance for the times to come, or even for the times at hand. From such a futurist perception of reality, tradition, any tradition, is suspect and to be spurned as an obstacle to the flowering of genuinely human potentialities.

Daly's real quarrel is with what she denominates as "the exploitative sexual caste system," which she perceives to have been somehow engendered by the patriarchal religion of "Yahweh \& Son." Consequently, although she does have good words for studies such as J. J. Bachofen's Das Mutterrecht, she is basically indifferent to historical research. Despite the work of Leonard Swidler and others, establishing that Jesus was a feminist, she boldly asserts that "sexist bias is endemic to and therefore perpetuated by Christianity." Her own experience appears to be the norm; and her resentment is against the assumption that past history "has some sort of prior claim over present existence, as if recourse to the past were necessary to legitimate experience now." Her own experience is the criterion, not only for her theology but also for establishing matters 
of fact. Unfortunately, this makes theological discourse difficult, for when theologians are unable to appeal to anything outside their own immediate experience, their arguments tend to become (pardon the phrase!) ad hominem.

The question, then, which may deserve more reflective thought is whether there are persistent structures in human life, so that the past may still be paradigmatic for the present; or whether the changes in human life have now so outmoded the continuities that the past no longer shapes the future or even illumines the present. The basic question may be: How radical really are our transformations of consciousness? Perhaps Mary Daly's own casual espousal of Bachofen's historical argument that matriarchy preceded patriarchy may prompt her to rethink and nuance her response to the question whether theology is to be done de novo. For is it true to suppose that theology, or any form of human thinking for that matter, can proceed without being somehow fathered and mothered by tradition?

\title{
A SHORT ESSAY ON HEARING AND ON THE QUALITATIVE LEAP OF RADICAL FEMINISM
}

\author{
Mary Daly
}

I think that I must begin with some comments about the problem of the context of discussion. Beyond God the Father was written in a new context. It was possible to write new words because of a new consciousness in a cognitive minority of women, because of the supportive hearing of such women. As Professor Nelle Morton has said: "In the beginning was the hearing." If I may be so tasteless as to quote my own book:

It would be a mistake to imagine that the new speech of women can be equated simply with women speaking men's words.... Words which, materially speaking, are identical with the old become new in a semantic context that arises from qualitatively new experience.

Radical feminism involves a qualitative leap beyond the symbols and ideologies of patriarchy-hence, beyond patriarchal religion. Radical feminist consciousness has an inherent dynamic, an intrinsic logic that points outside the "sacred canopy" of oppressive religious 
myths and symbols. In its deepest dimension, the women's revolution is postchristian. More about this later.

June O'Connor's lead article is perceptive. She recognizes that, unlike liberation theologians such as Cone and Gutierrez, I refuse to locate legitimation and support in traditional doctrines. She understands that the book is not merely an attempt to recast theology within the new perspective of women's liberation, but rather to surface the destructive powers within the myths of patriarchal religion and then move beyond these. She does appear, in that article, to be hearing.

In June O'Connor's "critical response," however, something else entirely is going on. She asks whether I "compromise revelation and the centrality of Christ." But clearly my book is saying that to assert the "centrality of Christ" (which is named Christolatry) is to compromise revelation, the living revelation that is happening in the lives of women breaking through to consciousness now. Since the Christ symbol is a uniquely male symbol for divinity, it is oppressive. It says: "For men only."

Am I more in the tradition than I realize? I hope not. Postchristian feminism does not need such unsolicited "baptism." Christianity can "include" feminism only in the sense that a cannibal includes his meal. "A suspension of revelation in the name of the ethical?" No. This idea is self-contradictory. Rather, in renaming good and evil, that is, in the living process of transvaluating values, the women's revolution is revelatory.

In order to respond to June O'Connor's second question, I have to try to hear what she is asking. Do I really mean that sexism is the key paradigm of all other forms of oppression? Yes. Is there a causal connection? Yes. Socialization of males to sexual violence, to rapism, is causally related to the rape of the land and water, the rape of the poor, of Blacks, of the Third World. Patriarchal religion, through the myth of feminine evil, has perpetuated a scapegoat syndrome which sets up a pattern for the scapegoating of ethnic and other minorities, all of which, of course, include women at the bottom of their respective hierarchies.

Behind and around and underneath all of June O'Connor's questions I think I hear one question: "You don't really mean it, do you?" A few years ago, radical feminist poet Robin Morgan wrote: "Good-bye to all that." It is difficult, sometimes, to hear another say "Good-bye," especially if there are obstacles in the way of one's own movement. To answer you directly: It is understandable that your persuasion should be unstable and short-lived. That is the story of cognitive minorities constantly overwhelmed by the Maya of the prevailing sense of reality. Sisterhood, the bonding of women, helps 
to dispel the Maya. I leave it to you to draw the personal and logical conclusion.

Wilma Gunsdorf von Jess comments that the book may call for the attention of men perhaps more than of women. Why? The fundamental change that has to take place, that is taking place, is in the consciousness of women. "Dialoguing" with men about feminism at this point in history drains energy and changes almost nothing. If Beyond God the Father calls, it is to women.

The issue of sacrifice is important. Clearly, self-destructive suffering, internalization of the scapegoat role assigned to women, is not a positive value. This is "masochistic liberation," which keeps women in bondage. However, there is another kind of suffering which is involved in working actively for liberation of oneself and one's sisters. Since the word "suffering" has passive connotations, I prefer the word struggle to describe this active working against blockages to becoming. Radical feminism entails risk, living dangerously. However, I would not call this "personal alienation." Rather, it is the cost of embarking upon a process of de-alienation, that is, of affirming the self over against alienating roles imposed in a sexist culture. Such a style of existence is indeed complex, but it is not a "dual" existence. Feminist consciousness is a process of integration as well as transformation.

In an oppressive situation-which is the situation of all women on this planet-the most loving thing one can do is to destroy the oppressive situation by affirming the self. This means that a new kind of relationship becomes possible. By ceasing to be magnifying mirrors for men, women offer men the opportunity to see through the webs of self-delusion continually spun out by the sexual caste system. It is unlikely that many men at this point in history will accept this offer. As Phyllis Chesler pointed out in Women and Madness, women will have to transfer the primary force of our "supportiveness" to ourselves and to each other-and never to the point of self-sacrifice. The crucifix is not a model for women. Rather, it functions as an odious reinforcement of socialization into the victim's role.

To Elisabeth Schuissler Fiorenza I can only point out that all concepts are derivative. To say that concepts are derivative from the Christian tradition (or from Marxian theory, or from Aristotelian philosophy, or from Freudian theory, or from American culture) says little about the value of the concepts. To deny the existence of sources would be to deny the reality of process and of causality. I do think it is the case that the primary sources of feminist philosophy are the data of women's experience. Documents written by men can function only as secondary sources. And, especially when considering 
these secondary sources, I think it is important to be constantly aware that it matters more where we are going than where we started from.

Radical feminist philosophy is a process which begins with criticism of inherited ideologies, symbol systems, "methods." It is a process which has its own intrinsic dynamics. I perceive those dynamics as moving an ever-increasing number of women into a postchristian time/space, a state of consciousness in which the Christian symbol system is recognized as inherently sexist. As our psychic and cultural situation changes, the old myths lose their credibility. I sense that the unifying theme in Elizabeth Schuissler Fiorenza's various statements is basically a refusal to follow through the logic of these dynamics.

The women's movement is about women making a journey together. To make that journey it is necessary to confront the fact that instant "androgyny" is not available. There is no easy reconciliation and cheap grace. I do not use "the category of friend/friendship" for the simple reason that the women's revolution is about a specific kind of bonding: sisterhood, which is the bonding of women for our own becoming. Sisterhood implies the recognition that the bonding of women is the only hope for universal human becoming. It involves a steadfast refusal to sell ourselves short in the name of a delusory instant "human liberation."

Concerning John E. Burkhart's title, I must point out that the term "orphan" is accurately used to describe a child, not an adult. Insofar as I have achieved adulthood, I am incapable of being an orphan. Burkhart suggests that I perceive the sexual caste system as engendered by $\mathrm{Y}$ ahweh \& Son. No, it is more reasonable to suppose that Yahweh and Son were engendered by the patriarchal system. So were many other religious myths, since patriarchy is wider than Judeo-Christian culture. However, these symbols do function to maintain the patriarchy, to legitimate it as the will of God. As for the remarks about my "experience," Burkhart may have noticed that my book was not an autobiography, but rather a carefully researched work. Indeed, I do analyze the data out of my own experience and that of a growing cognitive minority of women. John Burkhart need not apologize for his use of the phrase ad hominem, since I do belong to the species homo sapiens, although not to the sub-species vir.

I think I must return to my initial comments about the context of this discussion. When it was proposed that some responses to Beyond God the Father be published in Horizons together with a response to these responses by myself, I had serious doubts about the value of such an experiment, but it seemed acceptable to let the experiment work itself out. One result has been a display of a basic 
contradiction. The contradiction is between the context, that is, the sense of reality, represented by a journal such as Horizons, and the context, that is, the experiential sense of reality, represented by Beyond God the Father. The horizons of Horizons are Christian. The time/space Beyond God the Father is Postchristian. Let me put it another way-rather bluntly, perhaps. One who would be comfortable writing for the journal of the College Theology Society would be uncomfortable hearing my book, even though she might be inclined to read it and to comment upon it. By hearing, I do not mean agreeing on every point. Rather, I mean being-in-communication, a situation in which energizing dialogue-hurling ideas further and further can take place.

Yet there is a process, beyond Horizons and beyond Beyond God the Father, where the experiences of women meet. That process is the Verb in which we participate by being the verbs who we are. Therein lies the hope-active, creative, political hope-of real hearing and conversation. 